\title{
Církev v poslání Ježíše Krista: diakonické jednání mezi sborem, společenstvím a společensky prospěšnými organizacemi ${ }^{1}$ Annette Noller
}

\begin{abstract}
Abstrakt
Tento článek představuje teorie církve, které jsou v současnosti rozvíjeny v německé evangelické teologii. Věnuje se úhlům pohledu, z nichž se na tyto teorie církve dívá luteránská diakonie. Diakonické jednání se stává viditelné jako forma činnosti církve v sociálně diferencované společnosti. Na pozadí procesů hluboké společenské proměny a stále klesajícího počtu lidí hlásících se k evangelickým církvím v Německu článek pojednává o otázkách budoucího rozvoje církve. Podle současných teorií praktické teologie je potřeba evangelium komunikovat v mnohých organizacích a rozmanitých profesích, aby bylo schopno oslovovat lidi různých společenských postavení a z různých prostředí. Z této perspektivy Ize na diakonické organizace a diakonickou angažovanost hledět jako na zvláštní tvar církve, v níž se evangelium Boží výkupné lásky představuje jako láska k bližnímu. Článek přináší metody managementu a příklady diakonického vzdělávání, které mají za cíl komunikovat diakonický rozměr evangelia v rámci farností, ale také ve společensky prospěšných organizacích, které svým pưsobením zastupují sociální stát.
\end{abstract}

\section{1. Úvod: Církev - současné teorie církve ${ }^{2}$}

\subsection{Co je církev?}

V celém průběhu dějin církví ekleziologické koncepty vždy proměňovaly a aktualizovaly víru. Němečtí praktičtí teologové předpokládají, že v Bibli je výraz „církev“ neostrý, zahrnuje např. shromáždění jako „Boží lid putující světem“ (List Židům), „zbožná skupinka“ vyvolených (Evangelium podle Lukáše), „tělo Kristovo“ (Pavel), či „učedníci poslaní do světa“ (misie a misijní

1 Tento článek je založen na osm let trvající výzkumné činnosti, která zahrnovala dvě sociologická zkoumání. Text je z větší části založen na přednášce s názvem „Komunikovat evangelium na mnoha místech. Teologie, teorie církve a sociologické aspekty současné církevní praxe“, kterou jsem přednesla v Melbourne 2.- 4. září 2016. Australská konference, již organizoval John Flett, byla odpovědí na konferenci Sjednocená církev a sjednocená péče (United Church and United Care). Př́spěvky z konference Znovu získat svou duši (Recapturing our Soul) ještě nebyly publikovány, budou ale publikovány v budoucnosti.

2 Annette NOLLER, Diakonat und Kirchenreform. Empirische, historische und ekklesiologische Dimensionen einer diakonischen Kirche, Stuttgart: Kohlhammer, 2016; Annette NOLLER, Diakonat und Kirchenreform. Beiträge der Diakonatsforschung zur Kirchentheorie und -praxis, Praktische Theologie 4/2016, s. 234-241. 
poslání). ${ }^{3} \mathrm{~V}$ evangelické teologii se při definování církve obvykle cituje článek VII Augsburského vyznání (1530): podle této definice je církev „...Shromáždění všech věřících, mezi nimiž se evangelium káže čistě a svátosti jsou vysluhovány podle evangelia. “4 Toto pojetí církve je založeno na kázání a svátostech. Z pohledu luteránské dogmatiky je církev stvořena Božím slovem, které slibuje vykoupení hříšníkům a utěšuje věřící Boží milostí. Sbor se svými bohoslužbami je hlavní místo, kde se věřící setkávají a praktikují svou víru. Avšak reformace byla mnohem víc než jen čas modlitby a kázání. Byla také začátkem náboženského vzdělávání ve školách, $\mathrm{v}$ domácnostech (katechismus) a konfirmačního vyučování. Po staletí se evangelické církve šiřily také skrze diakonické a vzdělávací činnosti.

Ve 20. století se v Německu vyvinul nový typ sboru kolem sborových domů (Gemeindehaus). Členové církví se nadále věnovali nejen naslouchání evangeliu, ale také se setkávali ve skupinkách, kde diskutovali nad biblickými texty, zapojovali mládežnické skupiny, snídaně žen, sirotčí skupiny, dětskou bohoslužbu, farní oslavy, exkurze atd. Vznikaly nové církevní profese, jako jsou sboroví pedagogové (Gemeindepädagoge), a metody, jako je zážitková pedagogika (Erlebnispädagogik). Německé praktické teologie reflektovaly nové teorie církve. Starší dogmatická pojetí církve byla revidována s využitím sociologických metod. Tím se evangelický dogmatický pohled na pojetí církve proměnil.

V tomto kontextu v období více než třiceti let odhalily průzkumy a sociologická zkoumání týkající se Německé evangelické církve (Evangelische Kirche in Deutschland: EKD) a diakonie data, která mají převážně co do činění s významy, osobními závazky a církevní příslušností. Jsou posbírána od př́slušníků i ne-př́slušníků EKD a jejich místních sborů. ${ }^{5}$ Sociologické teorie, jako nap̌r. teorie systémů, ${ }^{6}$ inspirovaly praktické teology k inovativním způsobům uvažování o církvi a diakonii. Jedním $\mathrm{z}$ výsledků je vhled, že v moderních diferencovaných společnostech se církve nevyvijejí jen $v$ jedné společenské formě, ale $v$ mnoha organizačních formách.

Toto chápání provázel paradigmatický posun $\mathrm{v}$ definici církve v německé evangelické praktické teologii. Parafrázujeme-li slavnou formulaci Ernsta Langese, úkol církve je v současných publikacích definován jako „komunikování evangelia“? Paradigmatický posun vede od kázání ve sborech k širšímu pojetí církve jako komunikace evangelia "na mnohých místech“. ${ }^{8}$ Aby upoutalo a získalo církevní př́slušníky, musí být evangelium komunikováno co největšímu počtu lidí (Mk 16,15; Mt 28,18-20) v mnoha profesích, institucích a komunikačních formách. Tento

3 Friedrich WINTZER, Praktische Theologie, Neukirchen-Vluyn: Neukirchner Verlag, 1990, s. 20-28; Eberhard HAUSCHILDT - Uta POHL-PATALONG, Kirche: Lehrbuch Praktische Theologie 4, Gütersloh: Gütersloher Verlag, 2013, s. 19-21; NOLLER, Diakonat und Kirchenreform..., s. 86-89.

4 Původní německý text: „Versammlung aller Gläubigen, bei welchen das Evangelium rein gepredigt und die heiligen Sakraments lauts des Evangelii gereicht werden, "Confessio Augustana 1530, Art. VII, citováno z: Bekenntnisschriften der Evangelisch-Lutherischen Kirche, hg. im Gedenkjahr der Augsburgischen Konfession 1930, ${ }^{10} 1986$ (BSLK ), Göttingen: Vandenhoeck \& Rupprecht, s. 61; Jan HERMELINK, Kirchliche Organisation und das Jenseits des Glaubens: Eine praktisch-theologische Theorie der evangelischen Kirche, Gütersloh: Gütersloher Verlag, 2011, s. 43-46.

5 EVANGELISCHE KIRCHE IN DEUTSCHLAND (ed.): Engagement und Indifferenz. Kirchenmitgliedschaft als soziale Praxis. V. EKD. Erhebung über Kirchenmitgliedschaft, Hannover, 2014; Heinrich BEDFORD-STROHM - Volker JUNG (ed.): Vernetzte Vielfalt. Kirche angesichts von Individualisierung und Säkularisierung. Die fünfte Erhebung über Kirchenmitgliedschaft, Gütersloh: Gütersloher Verlag, 2015; Jan HERMELINK, Praktische Theologie der Kirchenmitgliedschaft. Interdisziplinäre Untersuchungen zur Gestaltung kirchlicher Beteiligung (APT 38), Göttingen: Vandenhoeck \& Ruprecht, 2000.

6 Niklas LUHMANN, Einführung in die Systemtheorie, ed. Dirk BAECKER, Heidelberg: Carl-Auer-Systeme Verlag, 2002/ ${ }^{6} 2011$; Niklas LUHMANN, Soziale Systeme. Grundriß einer allgemeinen Theorie, Frankfurt a.M.: Suhrkamp Verlag, 1984/ ${ }^{1} 1987$.

7 Ernst LANGE, Zur Theorie und Praxis der Predigtarbeit, in: týž, Predigen als Beruf. Aufsätze zu Homiletik, Liturgie und Pfarramt, ed. Rüdiger SCHLOZ, München: Chr. Kaiser Verlag, 1982, s. 9-52 (citát: s. 11); srov. Fritz LIENHARD, Grundlegung der Praktischen Theologie. Ursprung, Gegenstand und Methoden (APrTh 49), Leipzig: Evangelische Verlagsanstalt, 2012, s. 95-98 a s. 106-181; Christian GRETHLEIN, Praktische Theologie, Berlin/Boston: De Gruyter, 2012, s. 253-326; HAUSCHILDT - POHL-PATALONG, Kirche..., s. 411-415; NOLLER, Diakonat und Kirchenreform..., s. 92-95, 442-445.

8 NOLLER, Diakonat und Kirchenreform..., s. 84-86, 419-445 (citát: s. 84, 419, passim). 
paradigmatický posun má hluboké důsledky pro priority církevních aktivit, pro vzdělávání církevních profesionálů a pro přidělování zdrojů $\mathrm{k}$ dalšímu rozvoji církve. $\mathrm{V}$ důsledku tohoto paradigmatického posunu ukáže tento článek, jak sbory $a$ vzdělávací aktivity $a$ diakonická činnost společně rozvíjejí církve v diferencovaných formách a závazcích. Ukážeme, jak je každý způsob komunikování evangelia součástí pohledu na církev, která se rozvíjí jako tzv. „hybridni' ${ }^{\text {(c) }}$ organizace na „mnohých místech a v rozmanitých povoláních“.10

\subsection{Teorie církve: teologické a sociologické popisy církve}

Od roku 1972 objednávala Evangelická církev v Německu (EKD), která je největším svazem luteránských a reformovaných místních církví v celém Německu, reprezentativní průzkumy církevní př́slušnosti. Tyto průzkumy byly založeny na sociologických metodách, zejména s využitím dotazníků a rozhovorů. Dotazováni byli členové i nečlenové v desetiletých odstupech na svůj vztah $\mathrm{k}$ církvi, své zapojení $\mathrm{v}$ církvi, svá pouta $\mathrm{k}$ ní a na svá očekávání vưči církevní př́ślušnosti.

Podívejme se nyní na významné výsledky, které se týkají naší otázky po církvi a její společenské angažovanosti. Podle průzkumu z roku 2013 je asi 60 \% všech obyvatel Německa členy dvou největších křestanských církví a platí církevní daň jako jejich trvalí členové. Tyto dvě největší institucionální organizované církve jsou Evangelická církev v Německu (EKD) a Římskokatolická církev, k nimž oběma se hlásí asi $30 \%$ všech obyvatel Německa. Tato institucionální organizovaná forma evangelických a katolických církví trvale ztrácí členy, zejména oblastech, které byly dřive socialistické. Sociologické průzkumy však ukazují, že vazby těch, kdo jsou členy Evangelické církve v Německu (EKD), mají posledních čtyřicet let pevnou strukturu. Většina členů pocituje hlubokou spřízněnost se svou církví, zatímco jiní se necítí být své církvi názorově blízko. Jedním z klíčových zjištění těchto průzkumů členské základny v Evangelické církvi v Německu (EKD) je, že ačkoli se činnosti místních sborů a jejich bohoslužeb nadále účastní jen asi 10-15 \% všech členů, 73 \% členů přesto odpovídá, že „kategoricky“ (kategorisch) ${ }^{11}$ vylučují možnost, že by přestali být (daň platícím) členem své církve. Toto číslo odpovídá všem čtyřem posledním průzkumům, které EKD objednala. To vede k pojetí, že vazba k církvi není určována jen individuálním zapojením v místní farnosti. Ačkoli jsou faráři a farnosti nejlépe známé a nejvíce reprezentativní veřejné osoby a instituce v evangelických církvích, jsou i jiná kritéria církevní vazby a setrvávání v církvi. Tento jev objasňují další data, která se opakovaně objevují v posledních pěti průzkumech objednaných Evangelickou církví v Německu (EKD). ${ }^{12}$

Další významnou hodnotou $\mathrm{v}$ tomto kontextu je aspekt očekávání od církve, jak je prezentován ve všech průzkumech zaměřených na diakonickou angažovanost. V průzkumu z roku 2012, jehož výsledky byly publikovány v roce 2015 , byla položena otázka: „Nakolik by se měla církev angažovat v následujících oblastech?“” („Inwiefern sollte sich die Kirche in folgenden Bereichen engagieren? $\left.{ }^{“ 13}\right) .83 \% \mathrm{z}$ dotazovaných členů a nečlenů označilo jako první a druhou prioritu varianty

9 Eberhard HAUSCHILDT, Hybrid evangelische Großkirche vor einem Schub an Organisationswerdung. Anmerkungen zum Impulspapier ,Kirche der Freiheit' des Rates der EKD und zur Zukunft der Evangelischen Kirche zwischen Kongregationalisierung, Filialisierung und Regionalisierung, in: Pastoraltheologie 1/2007, s. 56-66 (citát: s. 56. Slovo „hybridní“ zavedl Hauschuldt); NOLLER, Diakonat und Kirchenreform..., s. 49-86.

10 Původní německý text: „Kirche an pluralen Orten in diversen Beauftragungen“ (NOLLER, Diakonat und Kirchenreform..., s. 414; 49-86); Uta POHL-PATALONG, Von der Ortskirche zu kirchlichen Orten. Ein Zukunftsmodell, Göttingen: Vandenhoeck \& Ruprecht, 2004/ 22006; HAUSCHILDT - POHL-PATALONG, Kirche...; Uta POHL-PATALONG - Eberhard HAUSCHILDT (Ed.), Kirche verstehen, Gütersloh: Gütersloher Verlag, 2016.

11 Einleitung, in: EVANGELISCHE KIRCHE IN DEUTSCHLAND (ed.), Engagement und Indifferenz, s. 17.

12 NOLLER, Diakonat und Kirchenreform..., s. 49-73.

13 Gerhard WEGNER - Anja SCHÄDEL: Diakonische Potenziale, in: EVANGELISCHE KIRCHE IN DEUTSCHLAND (ed.), Engagement 
odpovědi týkající se sociální angažovanosti církve. To zahrnuje, že „církev by měla pomáhat potřebným" " ${ }^{14}$ Bohoslužby a modlitba následovaly mezi prioritami až na třetí a čtvrté pozici. Vysoká důležitost přikládaná diakonické práci se nachází ve všech předchozích průzkumech, které byly vedeny stejným způsobem. To znamená, že většina členů i nečlenů očekává od církve odpovídající diakonickou angažovanost. Očekávají, že diakonické služby budou nabízeny, i když je oni sami nepotřebují.

Pojd’me se znovu podívat na výsledky průzkumu vedeného Evangelickou církví v Německu (EKD). Jeden z hlavních výsledků ukazuje, že členové církví sdružených v EKD jsou k těmto církvím připojeni tzv. „distancovanými“ zpo̊soby (distanzierte Kirchenmitgliedschaft). ${ }^{15} \mathrm{Ne}$ všichni z nich chtějí pravidelně a trvale docházet do farností. Většina členů realizuje svůj vztah k církvi občasnými kontakty. Většina členů také udržuje kontakt se svou církví prostřednictvím přechodových rituálů či biografických změn, které jsou doprovázeny př́ležitostnými bohoslužbami (Kasualien). Křest dětí, konfirmace mládeže, sňatky a pohřby jsou stále považovány za významné duchovní události a př́ležitosti k oslavě v rodinách i jednotlivě. Občasné kontakty, např. vánoční a velikonoční bohoslužby, jsou významné jako hlavní oslavy církevního roku. ${ }^{16}$

Teorie náboženské socializace ukazují, že pro lidi, kteří věří v křest’anského Boha, je významné rané vzdělávání, k němuž dochází v rodinách, školkách a školách. Konfirmační výuka a výuka náboženství pro dospělé, kterou církev nabízí, pomáhá prohlubovat víru. Významná jsou také církevní média a veřejné informace o církvi. Všechny tyto informace a vzdělávací nabídky zvou $\mathrm{k}$ účasti na náboženské komunikaci a jsou tedy součástí komunikování evangelia. Komunikovat evangelium na mnohých místech je potřeba $\mathrm{k}$ tomu, aby dosáhlo $\mathrm{k}$ členům i nečlenům $\mathrm{v}$ jejich odlišných individuálních biografiích a prostředích. Podle německé evangelické praktické teologie je tento pluralitní typ komunikování evangelia rozmanitými způsoby ${ }^{17}$ jedním $\mathrm{z}$ hlavních úkolů církví v sociálně diferencovaných moderních společnostech. Je výzvou pro úvahy o jednání a rozvíjení církve na mnohých místech nejen ve farnostech, ale také v oblastech diakonie, běžného života, kultury, médií a vzdělávání.

Tyto vhledy z rozličných teorií církve byly shromážděny a pojednány jako soubor teorií, které jsou výzvou pro rozvoj „církve na mnohých místech“ (Kirche an pluralen Orten) ${ }^{18}$. První, kdo nahlédl, že v dějinách i v současnosti mají farnosti svou důležitost pro rozvoj církve, byla Uta Pohl-Patalong, profesorka praktické teologie. Odhadovala však, že církve - jako veřejné instituce ve společnostech - se nikdy nerozvíjely pouze v podobě sborů. ${ }^{19}$ Po celé dějiny církví se křestanská víra šírila mnohými formami v širokém záběru diakonických a náboženských vzdělávacích a informačních nabídek. Eberhard Hauschild, německý evangelický profesor praktické teologie, našel metaforu pro rozvoj církve na mnohých místech: multi-perspektivní fenomény církve nazval „hybridni““20 Jako moderní auta, která jezdí na benzín i na solární motory, se i církev musí rozvíjet na základě rozličných zdrojů. Církve potřebují flexibilní motory, aby mohly efektivně fungovat.

und Indifferenz, s. 93-95 (citát: s. 93, obr. 1); NOLLER, Diakonat und Kirchenreform..., s. 69-71.

14 Původní německý text: „sich um Menschen in sozialen Notlagen kümmern“, tamtéž, s. 93.

15 EVANGELISCHE KIRCHE IN DEUTSCHLAND (ed.), Engagement und Indifferenz, s. 9; NOLLER, Diakonat und Kirchenreform..., s. 61-71.

16 Michael MEYER-BLANK - Birgit WEYEL, Studien- und Arbeitsbuch Praktische Theologie, Göttingen: Vandenhoeck \& Ruprecht, 2008, s. 83-93; NOLLER, Diakonat und Kirchenreform..., s. 75-80.

17 GRETHLEIN, Praktische Theologie..., s. 253; původní německé slovo: „Kommunikationsmodi“.

18 NOLLER, Diakonat und Kirchenreform..., s. 414.

19 Uta POHL-PATALONG, Gemeinde in historischer Perspektive, in: BUBMANN, Peter et all (ed.), Gemeindepädagogik, Berlin/Boston: De Gruyter, 2012, s. 37-60.

20 HAUSCHILDT, Hybrid evangelische ..., s. 56. 
Eberhard Hauschildt cituje v tomto kontextu habilitační tezi Geralda Kretzschmara, který dospěl $\mathrm{k}$ tomu, že „... připoutanost $\mathrm{k}$ církvi je biograficky utvořený produkt sebe-interpretace jedinců, v níž normální je být od této instituce vzdálen, a organizační integrace je zvláštní př́pad. ${ }^{21}$ Teoretici církve proto doporučují, aby se pozornost věnovala nejen farní podobě církví, ale i jejich jiným formám. ${ }^{22}$

\section{V Kristově poslání: dialkonická teologie a diakonická praxe}

Pohled na fenomén zvaný „církev“ mohou kromě sociologických teorií církve inspirovat také některé diakonické a teologické teze. Diakonická angažovanost komunikuje evangelium slovem a sociálním jednáním. Mnou sledovaná teze vyslovuje, že diakonie je specifický způsob, jak komunikovat evangelium v sociálním tvaru církve. Podívejme se tedy na naši otázku nejprve z teologického a zejména diakonického hlediska. ${ }^{23}$

\subsection{Diakonie a evangelium}

Evangelium vypráví, jak se Boží láska zjevuje v Ježiši Kristu. Ústředním tématem Kristova vtělení je sdělení Boží lásky $\mathrm{k}$ jeho omylnému světu. Tuto lásku lze spatřit v Božím vykoupení pro všechny hřrišníky. Lze ji spatřit ve způsobu, jímž Bůh zamýšlí obnovit společenství svého stvoření se sebou a jeho účast na sobě. V Ježíši Kristu se Bůh stává člověkem, sdílí svůj život s lidmi v duchovní a společenské nouzi, $v$ nemoci a bídě. Bůh poskytuje společenství těm, kdo jsou duchovně i sociálně chudí. Zabývá se těmi, kdo jsou nábožensky a sociálně stigmatizovaní a marginalizovaní. Tento diakonický dopad evangelia lze vysledovat ve vyprávěních o Ježiši Kristu. Je patrný v teologickém středu vykoupení. V Kristově ukřižování a vzkř́ǐ̌ení nejde jen o spásu jednotlivců:

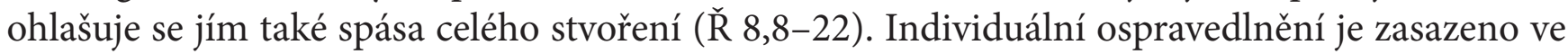
vizích sociální spravedlnosti a míru a v obnově celého stvoření (Zj 21,1-5). Bible interpretuje skutečnost, že Kristus je Mesiáš, v tradici osvobozující a útěšné milosti. Mluví se o ní v kritickém kontextu ve vztahu $\mathrm{k}$ nadvládě a $\mathrm{k}$ vykořistování, zvláště v tradici zastávání se chudých a utiskovaných, jak ji známe z Exodu a z prorockých tradic. Biblická vize „Božího království slibuje život v bratrství/sesterství a v solidaritě. Proto slavný německý teolog Dietrich Bonhoeffer řekl, že věřící se musí i modlit i praktikovat spravedlnost. ${ }^{24}$

Ve stř̌edu evangelia stojí tedy velmi silně sociální angažovanost. Není to něco, co by se dalo př́ležitostně přidat nebo vynechat. Láska k bližnímu (Nächstenliebe) a zastávání se chudých a utiskovaných nejsou druhotným či třetím aspektem evangelia po jiných, jako je kázání a modlení: stojí v samém středu evangelia, které ř́ká „miluj Boha a miluj svého bližního jako sebe sama“ (L 10,27). V křestanských farnostech obecně panuje přesvědčení, že praktikování blíženecké lásky

21 HAUSCCHILDT, Hybrid evangelische..., s. 62 (původní německý text: „... dass Kirchenbindung ein von Individuen biografisch erworbenes Produkt der Selbstdeutung ist, bei dem die Distanz zur Institution der Normalfall, die organisatorische Einbindung der Sonderfall ist."); Gerald KRETZSCHMAR, Kirchenbindung. Praktische Theologie der mediatisierten Kommunikation, Göttingen: Vandenhoeck \& Ruprecht, 2007; týž, Eintritt und Wiedereintritt in die Kirche, in: Praktische Theologie 4/2010, s. 225-231. NOLLER, Diakonat und Kirchenreform..., s. 84-86, 428-445.

23 Heinz SCHMIDT, Biblische Grundlagen der Diakonie, in: Fritz LIENHARD - Heinz SCHMIDT (ed.), Das Geschenk der Solidarität. Chancen und Herausforderungen der Diakonie in Frankreich und Deutschland (VDWI 28), Heidelberg, 2006, s. 112-133; NOLLER, Diakonat und Kirchenreform..., s. 23-32.

24 Původní německý text: „Unser Christsein wird heute nur in zweierlei bestehen: im Beten und im Tun des Gerechten unter den Menschen. Alles Denken, Reden und Organisieren in den Dingen des Christentums muß neu geboren werden aus diesem Beten und diesem Tun." Dietrich BONHOEFFER, Widerstand und Ergebung Briefe und Aufzeichnungen aus der Haft (Werkausgabe, Bd. 8), eds. Christian GREMMELS, Eberhard BETHGE and Renate BETHGE in Zusammenarbeit mit Ilse TÖDT, München: Gütersloher Verlagshaus, 1998, s. $435 n$. 
a diakonická angažovanost jsou formy následování Krista. V liturgiích raného křestanství bylo přijímání eucharistie spojeno s péčí o nemocné a chudé členy. Biskupové doporučovali jáhnům, aby přinášeli dary $\mathrm{z}$ agapé těm, kdo nemohli přijít. Jáhnové $\mathrm{v}$ rané církvi měli za úkol starat se o trpící, nemocné a chudé členy. Láska rané církve byla sdílena nejen s jejími vlastními členy, ale také s potřebnými sousedy z pohanského okolí. S tímto obětavým postojem blíženecká láska podporovala poslání a růst církve a prochází celými církevními dějinami. Byla praktikována v mnišské tradici a v období reformace byla chápána jako povinnost všech křestanů, otců a matek, občanů, řemeslníků a vůdců. V 19. století se v Německu diakonické základy udržely během průmyslové revoluce. Aby vzdělávali a podporovali děti ze sociálně znevýhodněných rodin, stavěli teologové jako Johann Hinrich Wichern tzv. „záchranné domy“ (Rettungshäuser) a vzdělávali diákony (Diakone), aby zachraňovali hladovějící a znevýhodněné děti z fyzické a duchovní tísně. Věřící jako Theodor Fliedner zakládali diakonické mateřské domy (Mutterhaus) a vzdělávali diákonky (Diakonissen), aby podporovaly chudé a živily zejména nemocné mezi nimi. ${ }^{25}$

Tyto instituce založené v 19. století v Německu existují dosud. Byly založeny jako od daní osvobozené obecně prospěšné spolky (gemeinnützige Vereine) a jsou dosud organizovány vedle církve jako náboženské instituce. Katolická Charita a evangelická Diakonie jsou dnes největší společensky prospěšné spolky v Německu, každá asi s půl milionem zaměstnanců a zhruba stejným počtem dobrovolníků. Působí v subsidiární spolupráci se státními subjekty a městskými zřizovateli v rámci německého sociálního státu. ${ }^{26}$ Prostředky získávají z daní, z příspěvkủ (Entgelte), z pojištění (zvláště zdravotního, Kranken- und Pflegeversicherung), z dalších veřejných zdrojů a ze soukromých darů. Německé diakonické subjekty, jako je např. Brot für die Welt (Chléb pro svět), se také významně diakonicky angažují v mezinárodní sociální práci. Vedle těchto velkých subjektů s velkým dosahem existují také charitní aktivity jednotlivých sborů a oblastních církví $\mathrm{v}$ Německu, které jsou také financovány $\mathrm{z}$ veřejných zdrojů a veřejných daní. Část diakonických projektů je financována $\mathrm{z}$ církevních daní a sponsoringu. $\mathrm{V}$ diakonických aktivitách církví se angažuje mnoho členů i nečlenů.

V posledních letech se v Německu objevily kritické hlasy, které se ptají, zda jsou tyto velké spolky ještě schopné jednat v souladu s tradicí křestanské víry. Tato otázka vyvstává, jakmile zaměstnanci velkých diakonických podnikůs stisícovkou zaměstnanců už nejsou přesvědčení křestané. Mimo to může být náplň jejich práce kontrolovaná a regulovaná systémem sociální péče. $V$ německé diakonické práci se může diakonický rámec a obsah stát pro partnery a klienty neviditelným. Nedostatek peněz a současný boj o zdroje $\mathrm{v}$ tzv. sociální tržní ekonomii přispěly $\mathrm{k}$ posílení diskuse o diakonickém profilu konkrétní diakonické práce.

\subsection{Diakonický profil pro diakonické organisace: diakonická korporátní kultura a firemní vize (Leitbilder)}

Jak lze mluvit o diakonické angažovanosti jako o zvláštním tvaru církve, jestliže klienti a partneři nerozpoznávají její křestanský obsah? Jak může být diakonická angažovanost viditelná jako forma křestanské víry? Německé diakonickovědné bádání (Diakoniewissenschaft) rozvinulo několik

25 NOLLER, Diakonat und Kirchenreform..., s. 209-366; táž, Der Diakonat - historische Entwicklungen und gegenwärtige Herausforderungen, in: táž a kol. (ed.), Diakonat - theologische und sozialwissenschaftliche Perspektiven auf ein kirchliches Amt, Stuttgart: Kohlhammer Verlag, 2013, s. 42-84.

26 Thomas OLK, Freie Träger in der Sozialen Arbeit, in: Hans-Uwe OTTO - Hans THIERSCH (ed.), Handbuch Soziale Arbeit. Grundlagen der Sozialarbeit und Sozialpädagogik, München/ Basel, 52015, s. 459-471; Ulli ARNOLD - Klaus GRUNWALD - Bernd MAELICKE (ed.), Lehrbuch Sozialwirtschaft, Baden-Baden: Nomos Verlag, ${ }^{4} 2014$; Johannes EURICH - Wolfgang MAASER, Diakonie in der Sozialökonomie. Studien zu Folgen der neuen Wohlfahrtspolitik (VDWI 47), Leipzig: Evangelische Verlagsanstalt, 2013. 
možných řešení, jak lze utvářet diakonické „proprium“ či tzv. „evangelický profil“. Několik z nich tu chci popsat.

Jedním z návrhů je zaměřit se na diakonický profil rozvíjením diakonické korporátní kultury. Dnes se ti, kdo analyzují globální problémy, i teoretici diakonie vážně zamýšlejí nad tzv. „měkkými faktory“ podniku, které jsou př́tomné v korporátní kultuře. To zahrnuje faktory, jako jsou firemní vize, chování, postoje, sdílená etika, korporátní design a pracovní atmosféra. Kultura $\mathrm{v}$ tomto kontextu pojímá všechny nástroje a faktory, které utvárí konkrétní vzhled a atmosféru organizace. Tato kultura je vědomě či nevědomě sdílena zaměstnanci diakonického podniku. Některé aspekty jeho kultury jsou viditelné a rozpracované v dokumentech, které odrážejí jejich tradice a uspořádanou strukturu. Beate Hofmann ukázala, že hlavní kořeny určité kultury jsou obvykle neviditelné. ${ }^{27}$ Je nevědomě sdílena chováním a návyky zaměstnanců i vedoucích pracovníků dané organizace. Kulturní návyky a s nimi spojené hodnoty lze dále utvrzovat managementovými strategiemi, jako je kultura připomínání zakladatelů a zakladatelek diakonie a kultury slavení s duchovními nabídkami ve formě modliteb a pobožností. Diakonickou kulturu lze posilovat lidsky př́iznivou pracovní atmosférou, která poskytuje př́ležitosti pro interakci a pro vyjádření stížností. Je možné ji utvářet týmovými diskuzemi o etice nebo poradenskými setkáními zejména $\mathrm{v}$ souvislosti s oblastmi zdravotní péče.

Běžným nástrojem diakonické kultury v Německu je objasnění firemní vize (Leitbild). V těchto prohlášeních diakoničtí poskytovatelé služeb (Anbieter) formulují své hlavní hodnoty a strategické záměry v klíčových větách. Tyto věty jsou obvykle vypracovány v integrativním procesu mezi vedoucími pracovníky a zaměstnanci diakonické organizace či subjektu. Tím jsou všichni zapojeni do procesu přemýšlení o hlavních hodnotách a vizích své práce. Tento proces ujištuje profesionály i dobrovolníky o cílech a hodnotách jejich pracoviště. Firemní vize ukazuje kulturu a hodnoty diakonické organizace na úvodní stránce jeho webových stránek. Klient a partneři tak mají prrístup $\mathrm{k}$ informacím o organizační identitě a operativních cílech daného poskytovatele diakonických služeb.

Aby se diakonická kultura rozvíjela tímto způsobem, musí vedoucí pracovníci a zaměstnanci komunikovat o svých diakonických etikách, postojích a tradicích. Jednou z nejdůležitějších možností při rozvíjení diakonické kultury, návyků a jednánív diakonických subjektech je další vzdělávání zaměstnanců i vedoucích pracovníků s cílem prohlubovat jejich etické a teologické poznání. ${ }^{28}$

\subsection{Diakonické vzdělávání, diakoničtí profesionálové a služby pro diakonické hybridní aktivity ve sborech a ve společnosti}

K rozvíjení mnohých způsobů komunikování evangelia ve sborech i v diakonických subjektech jsou potřeba dobrovolníci a profesionálové, kteří jsou vzdělaní v diakonické praxi. Mnoho německých diakonických subjektů poskytuje svým zaměstnancům další vzdělávání. Část tohoto dalšího vzdělávání se týká křestanské víry, diakonických tradic a etiky. Většina zaměstnanců německých diakonických subjektů jsou členy křestanských církví, roste ale počet těch, kteří nejsou.

27 Beate HOFMANN, Diakonische Unternehmenskultur, Stuttgart: Kohlhammer, 2008; Cornelia COENEN-MARX, Die Seele des Sozialen. Diakonische Energien für den sozialen Zusammenhalt, Neukirchen-Vluyn: Neukirchner Verlag, 2013; Georg SCHREYÖGG and Daniel GEIGER, Organisation. Grundlagen moderner Organisationsgestaltung, Wiesbaden: Springer; Gabler, ${ }^{6} 2016$.

28 NOLLER, Diakonat und Kirchenreform..., s. 168-173; Jochen-Christoph KAISER, Sozialer Protestantismus als ,kirchliche Zweitstruktur' [2001], in: Volker HERRMANN - Martin HORSTMANN (Ed.), Studienbuch Diakonik, Bd. 2: Diakonisches Handeln, diakonisches Profil, diakonische Kirche, Neukirchen-Vluyn: Neukirchner Verlag, 2006, s. 259-279, zvl. s. 278. 
Stále méně z nich má povědomí o obsahu evangelií, církevních vyznání a o diakonických tradicích. Další vzdělávání, konference a přednášky jsou tedy důležitými nástroji, které uvádí kolegy do diskursu o evangelických postojích, etice a víre.

Vedle těchto možností máme v Německu dlouhou a hlubokou tradici diakonických profesionálů, kteř́ jsou známi jako diákoni a diákonky (křestanští sociální pracovníci a sestry). V německých evangelických církvích tyto profesionální tradice, které byly založeny v 19. století Johannem Hinrichem Wichernem, Theodorem Fliednerem a jejich spolupracovníky, stále přetrvávají v moderních vzdělávacích formách. $V$ německé tradici se diákoni a diákonky převážně zabývají sociální prací a zdravotní péćí. $V$ evangelické tradici jsou chápáni jako církevní profesionálové, kteří ohlašují evangelium v Božím poslání, ne tolik slovem, ale především sociální angažovaností.

Mohlo by proto být př́nosné uvažovat o specificky křestanském vzdělávání pro sociální pracovníky, sestry a sborové pedagogy (Gemeindepädagogen), které by je jako profesionály v sociální práci, ošetřovatelství a pedagogice uschopnilo ke komunikování křestanské etiky, víry a postojů na jejich pracovištích. Mohli by na svých pracovištích kázat a modlit se, nakolik je to možné s ohledem na zázemí instituce. ${ }^{29}$ Přemýšlení o komunikování evangelia zapojením různých církevních profesionálů nabízí nové vyhlídky pro rozvoj církve. Diakonické př́istupy poskytují př́iležitosti pro těsný kontakt $\mathrm{s}$ každodenním životem, pro komunikaci s lidmi v sociálně rizikové situaci a otevírají brány do rozmanitých sociálních prostředí. Sociální angažovanost může také vést $\mathrm{k}$ etickým konfliktům a sporům způsobeným zásahy sociální legislativy a soutěživých tržních ekonomik. $\mathrm{V}$ těchto roztřišstěných a kontroverzních formách jednání by diakonické subjekty podléhající státní legislativě mohly být kritizovány ze strany jiných věrících. Avšak evangelium se dál komunikuje uprostřed omylnosti stvořeného světa prostřednictvím aktivního hájení práv chudých a znevýhodněných $\mathrm{v}$ politických oblastech společnosti. Vzdát se diakonické angažovanosti $\mathrm{v}$ jejích rozmanitých formách, $\mathrm{v}$ různých subjektech a organizacích by znamenalo vzdát se formy komunikování evangelia $\mathrm{v}$ široké oblasti společnosti a každodenního života a vzdát se odpovědnosti za sociální a zdravotní nouzi. Spíše než vzdávat se diakonické angažovanosti v sociálních organizacích se tedy zdá být slibnějším uschopnit zaměstnance $k$ tomu, aby v nich a skrze ně komunikovali evangelium.

\section{Závěr: Diakonické aktivity na mnohých místech pro komunikování evangelia v široké škále sborůn, společenství a diakonických organisací}

Můžeme tedy shrnout, že - podle současných německých evangelických teorií církve ${ }^{30}$ - hlavním posláním církví je komunikovat evangelium. $\mathrm{K}$ této komunikaci dochází $\mathrm{v}$ diferencovaných společnostech na mnoha místech a $\mathrm{v}$ mnoha organizačních formách. Zatímco ve farnostech musí být evangelium hlásáno hlavně farárii, lze ho také zároveň komunikovat na mnohých místech ve formě vzdělávání a diakonického jednání $\mathrm{v}$ rozmanitých službách, profesích a v činnosti dobrovolníkủ. Musí být komunikováno prostřednictvím sociálních a veřejných médií.

Ve stř̌edu všech strategií pro církev, která je rozšířena na mnoha místech jako např. ve sborech, různých společenstvích a společnosti, stojí teologicky inspirovaný pohled na církev. Ten je založen

29 NOLLER, Diakonat und Kirchenreform, s. 99-132; Táž, Ausbildungsfragen und Dienstaufträge, in: BAUR, Werner a kol. (ed.), Diakonat für die Kirche der Zukunft, Stuttgart: Kohlhammer Verlag, 2016, s. 131-141; Annette NOLLER, Diakonat und theologische Kompetenz, in: Ellen EIDT - Claudia SCHULZ (ed.), Evaluation im Diakonat. Sozialwissenschaftliche Vermessung diakonischer Praxis, Stuttgart: Kohlhammer Verlag, 2013, s. 406-431.

30 GRETHLEIN, Praktische Theologie..., s. 253-326; HAUSCHILDT - POHL-PATALONG, Kirche..., s. 411-415; LIENHARD, Grundlegung der Praktischen Theologie..., s. 95-98 a s. 106-181; NOLLER, Diakonat und Kirchenreform..., s. 92-95, s. 442-445. 
na vztahu k Boží výkupné lásce a k poslání kázat naději trpícímu stvoření (̌̌ 8,18-25). To lze uskutečňovat bohoslužbou, kázáním a přijímáním svátostí a také diakonickou angažovaností. Apoštol Pavel zdůraznil, že Kristovo tělo má mnoho rozličných údů (1 K 12,12nn; Ř 12,3nn). Hledíme-li na církev - z diakonického úhlu pohledu - jako na tělo Kristovo, potřebuje oči, uši, ústa, ruce, nohy, mozek, hlavu atd. Všechny údy, tedy i ty, které jsou znevažované a marginalizované, jsou pro fungování Kristova těla důležité. „A které pokládáme za méně čestné, těm prokazujeme zvláštní čest, a neslušné slušněji zahalujeme“ ř́íká Pavel (1 K 12,23). Pavlova ekleziologická koncepce je orientovaná na spoluúčast rozmanitých charismat a talentů. Je to inkluzivní koncept, jak apoštol Pavel stanovuje: „Trpí-li jeden úd, trpí spolu s ním všechny“ (1 K 12,26). K tomuto ztělesnění Krista dochází v celém stvoření. Rozvíjí se v církvi, která jedná a komunikuje na mnohých místech, v rozmanitých organizačních formách a rozmanitých společenských prostředích, a tím i v diferencovaných sociálních systémech jako náboženský a společensky odpovědný subjekt v moderní společnosti.

\section{Kontakt}

\section{prof. dr. Annette Noller}

Evangelische Hochschule Ludwigsburg

Paulusweg 6, 71638 Ludwigsburg, Germany

a.noller@eh-ludwigsburg.de 